\title{
FEW ASPECTS ON THE PROCEDURE OF NOTIFICATION FOR A PRELIMINARY RULING IN CRIMINAL MATTERS IN COMPARISON WITH THE ONES FOR CIVIL MATTERS \\ I. Boghirnea
}

\section{Iulia Boghirnea}

Postdoctoral scholar, "Acad. Andrei Rădulescu" Legal Research Institute of Romanian Academy

Lecturer PhD, Faculty of Law and Administrative Sciences, University of Pitesti

Correspondence: Iulia Boghirnea, Faculty of Law and Administrative Sciences, 71 Republicii Blvd., Pitesti, Arges County, Romania

Email: iuliaboghirnea@yahoo.com

\begin{abstract}
:
The article aims to continue the scientific research of a legislative instrument for the prevention of a divergent judicial practice, namely the procedure for notifying the High Court of Cassation and Justice to issue a preliminary ruling for solving certain law matters, this time performing a comparative analysis between the texts of the criminal and civil procedure code.
\end{abstract}

Key words: Criminal Procedure Code, Civil Procedure Code, High Court of Cassation and Justice, preliminary ruling, binding interpretation, unification of the judicial practices

\section{Introduction}

In the light of the new legislative reforms ${ }^{1}$, the authors of the codes have considered predictable the fact that the entrance into force of new texts may generate divergences in the interpretation of certain matters of law, reason for which was created a new procedural mechanism, "novel" for the Romanian procedural legislation, with the role of standardizing the interpretation of provisions and to prevent the apparition of a non-unitary practice of the courts.

This procedure is known as the solving of certain law matters, by decisions of the High Court of Cassation and Justice which are generally binding for the courts, in insuring the unitary interpretation and application of the laws.

\section{Main text}

The Supreme Court, the High Court of Cassation and Justice, based on its constitutional role stated by Art 126 Para 3 of the revised and amended ${ }^{2}$ Romanian Constitution, has the quality of ruling to solve certain matters of law, on whose clarification depends the solution of a pending litigation. A similar institution can also be found in France, this is why it is considered by literature ${ }^{3}$ that the Romanian legislator has as role model the institution for requesting a preliminary ruling from the French legislation.

\footnotetext{
${ }^{1}$ We mention that both procedure codes, criminal and civil, have simultaneously entered into force, on 1 February 2014.

${ }^{2}$ Aiming its competence in insuring the unitary interpretation and application of the law by the courts.

${ }^{3}$ I Deleanu, Noul cod de procedură civilă comentat, $1^{\text {st }}$ Vol., C.H. Beck Publ.-house, Bucharest, 2013 , p. 705 .
} 


\section{Boghirnea}

Other authors consider that both institutions, the French ${ }^{4}$ and the Romanian ${ }^{5}$ one, have as role model the procedure of preliminary questions addressed by the national jurisdictions of Member States to the Court of Justice of the European Union, the only one with competence to unitary interpret the law of the European Union ${ }^{6}$.

In the Recitals referring to the new Code of Criminal Procedure ${ }^{7}$ in the form sent to the Parliament, it is shown that the motive of inserting such procedure is "the creation of a new mechanism for the unification of the judicial practice to contribute, together with the referral in the interests of the law, the creation of a predictable jurisprudence which will lead to the reduction of the criminal trial". "To ensure the efficiency of this new mechanism, the decision of the High Court of Cassation and Justice, published in the Official Gazette, shall have a binding force both for the court which requested the solution of the matter of law, as well as for all the other courts"

1. In criminal matters, the new mechanism for solving certain matters of law stated by the new Criminal Procedure Code in Art 475-477' de lege lata states provisions from which we extract some general features, similar with the ones from the civil area9:

- The active procedural legitimation: the notification shall exclusively originate from the court invested with the awarding of a solution on the main issue of the matter on the criminal trial from the tribunal, court of appeal or High Court of Cassation and Justice;

- Special object: solving certain matters of law on which it depends the awarding of a solution on the main issue of the matter on the trial case pending before the court of law as final instance (tribunal, court of appeal, High Court of Cassation and Justice);

- The material competence of solving the matter of law: only the High Court of Cassation and Justice may solve the request for a preliminary ruling, within the special panel of judges stated by the law;

- Term of submission: the notification may be submitted during the trial of the case as final instance (tribunal, Court of Appeal, High Court of Cassation and Justice);

- The limits of judgment: the decisions shall be ruled only referring to the solving/clarification of a matter of law, not on the fact of the pending case;

- The effects of the decision ruled by the High Court of Cassation and Justice: the solution given the matters of law is mandatory for all the courts from its publication in the Official Gazette of Romania, Part I.

In our opinion, we add a seventh feature of this procedure, namely its optional feature, the panel of judges (the court) being the only one who can appreciate if it is necessary the

\footnotetext{
4 A.-M. Morgan de Rivery-Guillaud, La saisine pour avis de la Cour de Cassation (Loi n ${ }^{\circ}$ 91-491 du 15 mai 1991, décret n 92-228 du 12 mars 1992), Semaine juridique, 1992, I, Doctrine, $n^{\circ}$ 3576, pp. 173179.

${ }^{5}$ Ş. Beligradeanu, Reflecţii critice cu privire la caracterul vădit dăunător al bunului mers al justiţiei al reglementării în noul cod de procedură civlă a posibilităţii sesizării de către anumite instanţe judecătoreşti a Înaltei Curţi de Casaţie ş̧i Justiţie în vederea pronunţării unei hotărâri prealabile pentru dezlegarea unor chestiuni de drept, in Dreptul No 3/2013, p. 109.

${ }^{6}$ The court, according to Art 256 Para 3 TFEU, shall have jurisdiction to hear and determine questions referred for a preliminary ruling under Art 267 TFEU, "in specific areas laid down by the Statute". But, considering that the CJEU Statute has not been yet adapted to this matter, the Court of Justice is the only one competent to issue a preliminary ruling.

${ }^{7}$ Law No 135/2010 on the Code of Criminal Procedure, published in the Official Gazette of Romania, Part I, No 486/15 July 2010, with its subsequent modifications and amendments.

${ }^{8}$ See the Recitals regarding the new Code of Criminal Procedure, in its form sent to the Parliament. http://www.just.ro/Portals/0/Coduri/coduri_60309/Expunere\%20de\%20motive\%20Proiectul\%20Legii\%20privindC odul\%20de\%20procedura\%20penala-forma\%20transmisaParlamentului.doc, accessed on 1 March 2015.

${ }_{9}$ These are similar with the ones from the civil area. See in this regard, V.C. Ciobanu, Tr.C. Briciu, Cl.C. Dinu, Drept procesual civil. Drept execuţional civil. Arbitraj. Drept notarial. Curs de bază, Naţional Publ.-house, Bucharest, 2013, pp. 415-416.
} 
initiation of the prior procedure, no other participant having such right, even if the interested party would prove the fulfilment of the conditions for admissibility stated by Art 475 of the Criminal Procedure Code. Thus, the text does not compel the aimed courts to notify the Supreme Court to issue a preliminary ruling.

2. Regarding the admissibility conditions, Art 475 of the Criminal Procedure Code states that "If during trial, a penal of judges from the High Court of Cassation and Justice, from the court of appeal or tribunal, invested with the awarding of a solution awarding of a solution on the main issue of the matter on trial as final court, noting that there is a matter of law on whose ruling depends the settlement of the merits of the case, and on which the High Court of Cassation and Justice did not ruled in another preliminary ruling or in a referral in the interests of the law, nor is the object of a pending referral in the interests of the law, shall be able to notify the High Court of Cassation and Justice to rule a decision solving the matter of law for which it has been notified".

From the interpretation of this text we extract the conditions for admissibility of the notification of the High Court of Cassation and Justice, which must be met cumulatively, namely:

- The existence of a case subjected to trial;

- The existence of a matter of law;

- Over this matter the High Court of Cassation and Justice did not issued another preliminary ruling or decided in another referral in the interest of the law;

- This matter is not subject of a pending referral in the interest of the law;

- On the solution of this matter of law depends the awarding of a solution on the main issue of the matter on trial;

- The case is pending before the court of law, as final court the High Court of Cassation and Justice, the court of appeal or tribunal.

3. Though the Romanian legislator, in criminal matters, did not adopted the text identical regarding the conditions of admissibility stated by the new Code of Civil Procedure ${ }^{10}$ (Art 519), which expressly states the condition of the matter of law's novelty ${ }^{11}$, we consider that from the interpretation of the text of the Code of Criminal Procedure (Art 475) "on which the High Court of Cassation and Justice did not stated in a preliminary ruling or in a referral in the interests of the law" we extract the same conclusion, namely the idea that the matter of law must be new.

We argue with the interpretation given by the doctrinaires of the civil procedural area ${ }^{12}$ to the condition of the novelty of the matter of law, in the meaning that "it has not yet been settled by a preliminary ruling or by a referral in the interests of the law" 13 , has not been "already settled by another preliminary ruling or referral in the interests of the law"14 or the

${ }^{10}$ Law No 134/2010 on the Code of Civil Procedure, republished in the Official Gazette of Romania, Part I, No 545/3 August 2012, with subsequent modifications and amendments.

11 "If, during the trial, a panel of judges from the High Court of Cassation and Justice, of the court of appeal or of the tribunal, invested with the awarding of a solution on the main issue of the matter on the trial case pending before the court of law as final instance, noting that a matter of law, on whose decision depends the settlement on the merits of the case, is new and on which the High Court of Cassation and Justice did not ruled, nor it is the object of a pending referral in the interests of the law, shall be able to request the High Court of Cassation and Justice a preliminary ruling solving the matter of law for which it has been notified" (Art 519 of the Romanian Code of Civil Procedure).

12 In literature, was criticized this legal condition of novelty as being "pleonastic" and "upsetting". I. Deleanu, Tratat de procedură civilă, Noul cod de procedură civilă, $2^{\text {nd }}$ Volume, Universul Juridic Publ.house, Bucharest, 2013, p. 387, note 1.

${ }^{13}$ I. Deleanu, Tratat de procedura civilă., op cit., p. 387.

${ }_{14}$ G. Boroi, O. Spineanu-Matei, Noul cod de procedură civilă. Comentarii pe articole, $1^{\text {st }}$ Volume, Hamangiu Publ.-house, Bucharest, 2013, p. 1008-1010 


\section{Boghirnea}

High Court of Cassation and Justice has not "ruled regarding the matter of law"15, namely, in our opinion, on the text of the Criminal Procedure Code "it has not stated by a preliminary ruling or by a referral in the interests of the law" 16 .

Another argument would be the French model of this institution, where there is a similar one, the Court of Cassation having the possibility to issue opinions interpreting new legal provisions presenting serious difficulties ${ }^{17}$ for the judges of first instance, both in civil and criminal matters ${ }^{18}$. The legal framework of the procedure "saisine pour avis" of the Court of Cassation is Art 441-1 - 441-4 of the Code of Judicial Organization ${ }^{19}$. The criminal court may request the opinion of the Supreme Court, according to Title XXII (art 706-64 - next) of the Criminal Procedure Code, which adopted this procedure by the entrance into force of the Law No 1062/15 November 2001 on the communitarian security ${ }^{20}$. Thus, Art 441-1 of the Code of Judicial Organization ${ }^{21}$ states that "before ruling regarding a new matter of law, which has a serious and recurrent difficulty in numerous litigations, the courts may, by a decision which cannot be appealed, to request the opinion of the Court of Cassation", complying with the condition stated by Art 706-64, final thesis, of the French Code of Criminal Procedure ${ }^{22}$ - "No request for an opinion shall be submitted if, during the trial, a person is in remand custody or placed under judicial control".

The French legislator, in criminal area, has expressly stated the novelty as condition, but the Romanian legislator preferred to replace it, detailing and explaining this condition of admissibility by the High Court of Cassation and Justice, using the formula "has not yet issued another preliminary ruling or ruled in a referral in the interests of the law".

Certain French authors ${ }^{23}$ consider that, there are really two aspects of the novelty: (1) the Court of Cassation may not have yet ruled regarding the matter of law, i.e. the matter has not been solved by it; (2) it allows the faster unification of interpretation of the new rules of law, this mechanism being applied in the area of legislative reforms.

Together with other authors ${ }^{24}$ we consider that the legislator's purpose to state in the Code of Civil Procedure the condition of novelty insures the differentiation between the two

${ }^{15}$ M. Tăbârcă, Câteva consideraţii privitoare la competenţa Înaltei Curţi de Casaţie şi Justiţie de a pronunţa o hotărâre prealabilă pentru dezlegarea unei chestiuni de drept, in "In honorem Ion Deleanu" Volume, Universul Juridic Publ.-house, Bucharest, 2013, pp. 352-353.

${ }^{16}$ Which somehow details this attribute of the matter of law.

${ }^{17}$ I. Leş, Organizarea sistemului judiciar în dreptul comparat, All Beck Publ.-house, Bucharest, 2005, p. 57.

${ }^{18}$ In administrative matters, Art 12 of the Law of 31 December 1987, in front of the French State Council was created, within the administrative contentious reform, the procedure named renvoi pour avis (requests for a preliminary ruling), aiming to unify the interpretation of the law.

${ }^{19}$ By Ordinance No 673/8 June 2006 was republished the Code of Judicial Organization, Art 151-1 and next, becoming Art 144-1 and next, with the same content. In civil matters, this procedure of notification for an opinion was created in 1991 by decree.

${ }^{20}$ Official Journal of the French Republic (JORF), No 266/16 November 2001, p. 18215

21 "Avant de statuer sur une question de droit nouvelle, présentant une difficulté sérieuse et se posant dans de nombreux litiges, les juridictions de l'ordre judiciaire peuvent, par une décision non susceptible de recours, solliciter l'avis de la Cour de cassation" (Art 441-1 of the French Code of Judicial Organization).

22 "Les juridictions pénales, à l'exception des juridictions d'instruction et des cours d'assises, peuvent solliciter l'avis de la Cour de cassation en application de l'article L. 151-1 du code de l'organisation judiciaire. Toutefois, aucune demande d'avis ne peut être présentée lorsque, dans l'affaire concernée, une personne est placée en détention provisoire ou sous contrôle judiciaire" (Art 706-64 final thesis of the French Code of Judicial Organization).

${ }_{23}$ M. Jean Buffet, La saisine pour avis de la Cour de Cassation, www.courdecassation.fr, accessed on 1 March 2015.

${ }^{24}$ A. Cotuţiu, Unele considerații asupra hotărârilor prealabile pronunţate în materiiile dreptului civil şi penal, Curierul Judiciar No 10/2014, p. 559. 
procedures for unification of the judicial practice, as well as for the prevention of the preliminary procedure overlapping with the one of the referral in the interests of the law, the first one having the role to prevent such practice, and the second one having the role to remove such divergent practice between courts.

If the High Court of Cassation and Justice have been notified with the same matter of law and its solution is pending with a referral in the interests of the law, from the interpretation per a contrario of the civil and criminal procedure codes, the procedure in the interests of the law should be solved with priority. Until the solution of the referral in the interests of the law, the preliminary ruling procedure shall be "left aside" and shall be finalized by a decision rejecting the notification remained without object ${ }^{25}$.

4. Regarding the suspension of the pending case by the hearing report of notification, in criminal matters, it is optional until the issuance of the preliminary ruling for solving the matter of law. But, if the suspension has not been ordered together with the notification, and the judicial investigation is finished before the High Court of Cassation and Justice ruled regarding the notification, the court shall have to suspend the hearings ${ }^{26}$ until the decision of the High Court of Cassation and Justice (Art 476 Para 2 of the Criminal Procedure Code). We are talking about a mandatory suspension, because, if the court would issue a decision, it might result in an interpretation of the matter of law different than the one provided by the Supreme Court.

The text is different than the civil one, according to which the court has the obligation, by the hearing report of notification, to suspend the pending case until the preliminary ruling solving the matter of law.

5. Art 477 Para 1 of the Code of Criminal Procedure states that the High Court of Cassation and Justice, by its Panel for solving certain matters of law, shall rule regarding the notification by $a$ decision.

According to Art 477 Para 3 of the Code of Criminal Procedure "the solution given to matters of law is binding for all the courts from its publication in the Official Gazette of Romania, Part I'.

We consider this provision to be more inspired than the one from the Code of Civil Procedure, which states that "the solution given to matters of law is binding for the court which requested it from its ruling, and for the other courts from its publication in the Official Gazette of Romania, Part I' (Art 521 Para 3), because the panel of judges who notified the Court of Cassation and Justice is not present in the moment when the decision is ruled, without effective access to its content, until the moment of its communication ${ }^{27}$.

The compulsoriness of the decisions issued during the preliminary ruling procedure, both for all pending cases, as well as for those who shall be registered in courts after the preliminary ruling, insure the efficiency of the regulation, the procedure being similar to the European one, according to Art 267 TFEU.

\section{Conclusions}

As a conclusion, we consider the provisions of the Code of Criminal Procedure compared with the ones of the Code of Civil Procedure, regarding the preliminary ruling procedure, as being justified in this area because they need to be as accurate and clear as possible to leave no room for other versions, by interpretation.

\footnotetext{
${ }^{25}$ M. Tăbârcă, op.cit., p.354.

${ }^{26}$ If the defendant is placed in house arrest or is in remand custody, Art 208 of the Criminal Procedure Code shall be applied accordingly during the suspension.

${ }^{27}$ I. Deleanu, Noul cod de procedură civilă, Comentarii pe articole, 1st Volume, Universul Juridic Publ.house, Bucharest, 2013, p. 711
} 


\section{Boghirnea}

This form of dialogue between a judge from the court and a judge from the Supreme Court by the so-called preliminary ruling has as purpose the promotion and protection of the same values and principles, namely the compliance with, consolidation and unity of a domestic legal order, as well as the legal protection of citizens' rights.

It remains for time to prove the real efficiency of this new mechanism for the unification of the judicial practice - fundamental premise of the credibility of justice.

This paper has been financially supported within the project entitled "Horizon 2020 - Doctoral and Postdoctoral Studies: Promoting the National Interest through Excellence, Competitiveness and Responsibility in the Field of Romanian Fundamental and Applied Scientific Research", contract number POSDRU/159/1.5/S/140106. This project is co-financed by European Social Fund through Sectorial Operational Program for Human Resources Development 2007-2013 Investing in people!

\section{References:}

1. G. Boroi, O. Spineanu-Matei, Noul cod de procedură civilăa Comentarii pe articole, $1^{\text {st }}$ Volume, Hamangiu Publ.-house, Bucharest, 2013

2. V.C. Ciobanu, Tr.C. Briciu, Cl.C. Dinu, Drept procesual civil. Drept execuţional civil. Arbitraj. Drept notarial. Curs de bază, Naţional Publ.-house, Bucharest, 2013

3. I. Deleanu, Noul cod de procedură civilă, Comentarii pe articole, $1^{\text {st }}$ Volume, Universul Juridic Publ.-house, Bucharest, 2013

4. I. Deleanu, Tratat de procedură civilă, Noul cod de procedură civilă, $2^{\text {nd }}$ Volume, Universul Juridic Publ.-house, Bucharest, 2013

5. I. Leş, Organizarea sistemului judiciar în dreptul comparat, All Beck Publ.-house, Bucharest, 2005

- Articles

1. M. Jean Buffet, La saisine pour avis de la Cour de Cassation, www.courdecassation.fr, accessed on 1 March 2015

2. A. Cotuţiu, Unele consideraţii asupra hotărârilor prealabile pronunţate în materiiile dreptului civil şi penal, Curierul Judiciar No 10/2014

3. M. Tăbârcă, Câteva consideraţii privitoare la competenţa Înaltei Curţi de Casaţie şi Justiţie de a pronunţa o hotărâre prealabilă pentru dezlegarea unei chestiuni de drept, in "In honorem Ion Deleanu" Volume, Universul Juridic Publ.-house, Bucharest, 2013

4. A.-M. Morgan de Rivery-Guillaud, La saisine pour avis de la Cour de Cassation (Loi $n^{\circ} 91$ 491 du 15 mai 1991, décret $n^{\circ}$ 92-228 du 12 mars 1992), Semaine juridique, 1992, I, Doctrine, $\mathrm{n}^{\circ} 3576$

5. Ş. Beligradeanu, Reflecţii critice cu privire la caracterul vădit dăunător al bunului mers al justiţiei al reglementării în noul cod de procedură civlă a posibilităţii sesizării de către anumite instanţe judecătoreşti a Innaltei Curţi de Casaţie şi Justiţie în vederea pronunţării unei hotărâri prealabile pentru dezlegarea unor chestiuni de drept, in Dreptul No 3/2013

- Websites

http://www.just.ro/Portals/0/Coduri/coduri_60309/Expunere\%20de\%20motive\%20Proiectul\%20Legii\%20privindC odul\%20de\%20procedura\%20penala-forma\%20transmisaParlamentului.doc, accessed on 1 March 2015 